\title{
Stump-harvesting for bioenergy probably has transient impacts on abundance, richness and community structure of beetle assemblages
}

\author{
Karen D. Shevlin*, Roseanne Hennessy*, Aoife B. Dillon†, Philip O’Dea†, Christine T. Griffin* \\ and Christopher D. Williams \\ *Behavioural Ecology and Biocontrol, Department of Biology, Maynooth University, Maynooth, Ireland, ${ }^{\dagger}$ Coillte Teoranta, Newtownmountkennedy, \\ Ireland and ${ }^{\ddagger}$ School of Natural Sciences and Psychology, Liverpool John Moores University, Liverpool, L3 3AF, U.K.
}

\begin{abstract}
Harvesting of tree stumps for bioenergy is popular and, although the environmental impact has been considered with respect to ecosystem processes, there have been fewer studies on the impact of stump-harvesting on biodiversity.

2 We carried out pitfall-trap surveys of beetle communities at eight plots across four sites (four plots were clear-fells where stumps remained and four were clear-fells where stumps were harvested). Initially, we recovered 7743 beetles when stumps were extracted but still on site (Year 1). All beetles were identified to family level and ground beetles and wood-associated beetles to species level. One year after stumps were extracted, the survey was repeated. In this collection, 2898 individual beetles were recovered.

3 In Year 1, stump-harvesting had a negative impact on beetle abundance and richness. However, 1 year after stumps were removed, there were no significant differences in these variables at any site.

4 At the community level, stump-harvesting weakly but significantly, affected carabid composition. One year after stumps were removed, stump-harvesting had no effect on community composition.

5 Stump-harvesting initially negatively affects beetle abundance, family-richness and carabid species richness, as well as community structure, although any effects are not large, are site-specific and are probably not persistent.
\end{abstract}

Keywords Coleoptera, community ecology, environmental impacts, species richness, stump-harvesting.

\section{Introduction}

With the drive to reduce dependence on imported fossil fuels, harvesting stumps in plantation forests has been proposed by many as a sustainable solution (Eustafor, 2010). Stump-harvesting differs from the traditional stem clear-fell harvesting system in that, in the case of the former, the main bole of the stump and many of its associated roots are mechanically removed from the ground and taken off site. In Europe, stump-harvesting has been practiced from the 1970s onward in Scandinavian countries (Hedman, 2008) and, more recently, in Ireland and the UK (Anonymous, 2009). The advantages of stump-harvesting include recovering a large amount of useable

Correspondence: Christopher D. Williams; e-mail: chris.david.williams@gmail.com biomass, reduced site cultivation costs and reduced breeding habitats for economically important pests such as the large pine weevil, Hylobius abietis (L.). Potential disadvantages can be economic or environmental (Walmsley \& Godbold, 2010). Adverse economic impacts may include the loss of nutrients from the soil, jeopardizing site fertility for the next plantation cycle (Kimmins, 1977; Mann et al., 1988, Walmsley \& Godbold, 2010) particularly for Norway spruce sites (Egnell, 2016) and the environmental impacts include possible eutrophication (Staaf \& Olsson, 1994) and siltation of local water courses (Anonymous, 2009). In addition, there may be a direct loss of $\mathrm{CO}_{2}$ from the disturbed soil, which could be particularly important on clear-fells with high soil organic matter (Ågren \& Hyvönen, 2003; Anonymous, 2009). Victorsson and Jonsell (2013a) showed that stump storage piles on the side of the road 
can be a severe 'ecological trap' for four species of saproxylics. Also, there is the potentially negative effects of stump-harvesting on biodiversity.

In a review of the effects of fuelwood harvesting on biodiversity in Europe, Bouget et al. (2012) concluded that 'large-scale fuelwood removal may, on a landscape scale, jeopardize the amounts and diversity of substrate that saproxylic organisms require as food and habitat'.

Carabidae have proven to be excellent bioindicators as a result of an extensive knowledge of their biology, in a variety of systems, and they are especially useful in studying disturbance (Rainio \& Niemelä, 2003). A recent study by Work etal. (2014) shows that, in terms of their community composition, Carabidae respond to dead wood removal in clear-felled forests of western Quebec. Nittérus et al. (2007) examined the effects of harvesting logging residues from clear-cuts on carabid diversity and composition. They found that the number and diversity of carabid species were significantly higher in clear-cuts with slash harvest (i.e. harvest of logging residues) than in control sites where slash was left on the ground. In all clear-cuts, slash removal caused an increase in generalist species and a decline in forest species.

Although there have been studies (see below) on the effects of stump-harvesting on saproxylics, there have been fewer studies on the effects of stump-harvesting on the nonsaproxylic species. Kataja-aho etal. (2016) noted that the numbers of arthropods between treatments were rather similar and that, for ground beetles, open-habitat and generalists benefitted from stump-harvesting. Persson etal. (2013) found that six species/taxa had higher abundances in stumps and that Diplopoda were much more abundant in bark than soil. Malmström (2012) showed that Collembola could survive the entire forest cycle in stumps and Battigelli etal. (2004) showed severe effects of stump-harvesting on oribatid mites.

We address this gap in studies by examining the initial and post-removal effects of stump-harvesting on beetle families (Coleoptera), ground beetle (Carabidae) species and saproxylic species through pitfall trapping at four sites with eight paired plots [clear-felled and stump harvested plots versus clear-felled plots (control) only]. Our primary objective was to look at effects on Carabidae and other nonsaproxylic ground-dwelling species. However, we also separately analyzed saproxylic species that we caught (even though pitfall trapping is not a recommended method of collection for such species, although it has been used to look at certain species such as pine weevil). We would expect saproxylic abundance to be highest in the first year and diversity to increase with stump age (Jonsell etal., 2007; Stenbacka et al., 2010; Lee et al., 2014). Stump-harvesting is a two-three stage process: once stumps are removed from the soil, they are temporarily left on site in wind-rows to undergo a 'weathering period'. This initial drying period can last 6-12 months, after which the stumps are moved to roadside for further weathering (a further 3-12 months), prior to dispatch to a processing facility. In the present study, we test the effects of initial stump-harvesting when harvested stumps were still present in wind-rows, as well as the long-term effects of stump-harvesting 1 year after stumps had been taken off-site to a processing facility.
Because the removal of stumps removes niches, our hypothesis is that stump-harvesting will adversely affect beetle abundance and/or community structure. To test this:

1 We examined the effect of stump-harvesting on the abundance of Coleoptera in general, and Carabidae and saproxylics, in particular, on both organic and mineral soil clear-fells.

2 We also investigated whether family (coleopteran) and/or species (carabid and saproxylic) richness are also affected.

3 Finally, we determined whether the composition of beetle families, carabid species and saproxylic species are significantly different between sites where stumps are retained and where they are removed.

Our hypotheses are based on the fact that, although the stumps remain on site initially, once harvested, the physical structure of the habitat is altered through disturbance to such an extent that the habitat becomes unsuitable to many beetles that normally occupy these niches.

\section{Materials and methods}

Experiments were conducted on four sites in the south-east of Ireland (Table 1). Each site was a clear-fell of Sitka Spruce [Picea sitchensis (Bong.) Carr.]. Logging residues (small branches and twigs, etc.) were left on site throughout the entire experiment. The clear-fell site areas varied in size from 8 to 21 ha. At each site, there were two areas with plots in each: a plot in the stump-harvested area and a plot in the neighbouring control area. Each plot was approximately $10000 \mathrm{~m}^{2}$ in area. All areas were clear-felled in 2011 and stumps extracted from stump-harvested areas in the second week of May 2012 and left piled on site in wind-rows (rows of piled stumps on the site). Between $20 \%$ and $40 \%$ of stumps were left in situ in stump-harvested mineral soil trial sites, increasing to between $56 \%$ and $78 \%$ left on peat sites, where site conditions created difficulties in accessing all the stumps. These stumps were removed from the sites 6 months after extraction.

At each plot, 10 pitfall traps were located in two rows of five traps. Traps were spaced out to cover the full plot with a minimum 10-m buffer at the edge to avoid edge-effects. The two rows were separated by between 6 and $12 \mathrm{~m}$, and the traps in each row were separated by between 10 and $20 \mathrm{~m}$, depending on the shape and size of the plot. Traps on stump-harvested plots were placed between wind-rows and at the same distance apart on the associated control plots. Stump-harvested and control plots were at least $200 \mathrm{~m}$ distant from each other. Each pitfall trap consisted of a plastic pint cup (diameter $9 \mathrm{~cm}$, depth $13 \mathrm{~cm}$ ) placed so that the edge was just below the soil surface. Each trap was covered by a $15 \times 15 \mathrm{~cm}^{2}$ piece of corriboard supported by four $15-\mathrm{cm}$ nails, which acted as a rain cover. Traps contained $100 \mathrm{~mL}$ of ethylene glycol ( $20 \%$ by volume) and a small amount of detergent to break the surface tension.

Beetles were collected every 2 weeks between 4 July 2012 and 12 September 2012 (six collections) (Year 1). Six collections were also made in 2013 from 12 August 2013 until 28 October 2013 (Year 2). Differences in sampling dates were a result of logistical difficulties. In the second year of collections, pitfall 
Table 1 Names, locations and soil types of sites in the present study

\begin{tabular}{|c|c|c|c|c|}
\hline Site code & Site name & Grid reference & Soil type & Trap numbers used in Supporting information \\
\hline 1 & Coolbeggan West & IX 05774, IG 87643 & Mineral & $\begin{array}{l}1-10 \text { stump-harvested } \\
11-20 \text { control }\end{array}$ \\
\hline 2 & Coolbeggan & IX 04024, IG 87646 & Mineral & $\begin{array}{l}21-30 \text { stump-harvested } \\
31-40 \text { control }\end{array}$ \\
\hline 3 & Rossmore & IS 65156, IG 74825 & Peat & $\begin{array}{l}41-50 \text { stump-harvested } \\
51-60 \text { control }\end{array}$ \\
\hline 4 & Errill & IS 19039, IG 77167 & Peat & $\begin{array}{l}61-70 \text { stump-harvested } \\
71-80 \text { control }\end{array}$ \\
\hline
\end{tabular}

traps were placed as close as possible to the positions of the traps in the first year of collections. Collections were preserved in $70 \%$ ethanol. All Coleoptera were identified to family level in accordance with Joy (1976) and Carabidae were identified to species level using Luff (2007). Saproxylic species were identified to species using Joy (1976). Beetles collected at different times within a year were pooled for each trap and analyses were conducted with trap as replication.

Univariate statistical analyses included using a two-way analysis of variance (ANOVA) to test for the effect of site and treatment (stump-harvested versus control) and their interaction (site $\times$ treatment) on the abundance and richness (species or family) of the various coleopteran communities (i.e. on total abundance of Coleoptera, Carabidae and saproxylics and on family richness of Coleoptera, species richness of Carabidae and species richness of saproxylics). Univariate analyses were performed using SPSs, version 19 (SPSS, 2011). We also employed a more conservative analysis to strictly avoid any pseudoreplication, even though this was accounted for by the inclusion of 'site' as a factor in the two-way ANOva. For this, we pooled all collections from each site and performed a generalized linear model with a Poisson error function and two levels of the factor 'treatment' (i.e. control versus stump-harvesting).

Multivariate analyses included a multi-response permutationprocedure (MRPP), which tests for the effect of grouping variables (site, soil type and treatment), on the dissimilarity matrix of the species or families (response variables) by comparing the within-group homogeneity (measured as the chance-corrected within-group agreement) among grouping variables. A $P$-value is determined by Monte Carlo permutation of the dissimilarity matrix. Euclidean distance was used and 10000 permutations were run. A MRPP was used to assess the effects of site, soil-type and treatment (stump harvested versus control) on the composition of the beetle communities. MRPP measures the effect-size of a particular grouping variable through chance-corrected within-group agreement, which describes the similarity of within-groups. The $P$-value is obtained from Monte-Carlo permutation of the species matrix.

Indicator species analysis is a method by which the fidelity of certain species to particular levels of a grouping variable were assessed by computation of both the relative frequency and relative abundance of the species for each level of the factor under investigation; again, the $P$-value is determined by a permutation procedure. For visualization of community composition, a non-metric multi-dimensional scaling (NMS) ordination was produced. These plots were labelled according to the sites from which the beetles originated. Multivariate techniques were performed using PC ORD, version 5 (McCune \& Mefford, 1999; McCune \& Grace, 2002).

\section{Results}

\section{Effects of stump-harvesting and site on abundance and richness of Coleoptera}

In Year 1, a total of 7743 beetles were identified to family (20 families). Of these, 3769 ground beetles (Carabidae) were identified to species ( 29 species) and a further 133 individuals from families known to be saproxylic were identified to species (12 species). In Year 2, 2898 beetles were identified to family level. Of these, 2299 ground beetles were identified to species (14 species). Only six individuals of the second collection were saproxylic: all were H.abietis (L.). Complete lists of families (Coleoptera) and species (Carabidae and saproxylics) are given for both years of collection in the Supporting information (Appendices S1-S5).

Table 2 provides a listing of all families of Coleoptera, all species of Carabidae and all species of saproxylics and their abundances in Stump-harvested and control traps for the 2 years of the study. Ten families (including the most abundant: Carabidae) were more abundant in control compared with stump-harvested traps in Year 1. By contrast, eight families were more abundant in stump-harvested traps and one family was equally abundant in the two treatments. In Year 2, however, only three families were more abundant in control traps and seven families (including the most abundant: Carabidae) were more abundant in the stump-harvested plot.

In Year 1, 13 species of Carabidae were more abundant in control traps than stump-harvested traps and 12 species were more abundant in stump-harvested traps. One species was equally abundant in both treatments. By contrast, in Year 2 , six species were more abundant in control traps and nine were more abundant in stump-harvested traps. For saproxylics, eight species were more abundant in control traps than stump-harvested traps in Year 1 and four species were more abundant in stump-harvested plots. For Year 2, only H.abietis was collected and all six individuals came from control traps. It should be noted, however, that pitfall traps are not the best collecting method for saproxylics and so the results should be treated with caution. 
Table 2 Abundances of Coleoptera families, Carabidae species and saproxylics in stump-harvested and control traps over 2 years of the present study

\begin{tabular}{|c|c|c|c|c|}
\hline \multirow[b]{2}{*}{ Family/species } & \multicolumn{2}{|l|}{ Year 1} & \multicolumn{2}{|l|}{ Year 2} \\
\hline & Stump-harvested & Control & Stump-harvested & Control \\
\hline \multicolumn{5}{|l|}{ Coleoptera families } \\
\hline Biphyllidae & 2 & 0 & 0 & 0 \\
\hline Byrrhidae & 0 & 2 & 0 & 0 \\
\hline Cantharidae & 0 & 0 & 2 & 0 \\
\hline Carabidae & 1896 & 1915 & 1214 & 1098 \\
\hline Cerylonidae & 3 & 4 & 0 & 0 \\
\hline Chrysomelidae & 2 & 5 & 1 & 0 \\
\hline Coccinellidae & 0 & 0 & 1 & 0 \\
\hline Colydiidae & 0 & 0 & 0 & 1 \\
\hline Curculionidae & 57 & 68 & 0 & 6 \\
\hline Dytiscidae & 10 & 5 & 14 & 9 \\
\hline Elateridae & 0 & 1 & 0 & 0 \\
\hline Endomychidae & 1 & 0 & 0 & 0 \\
\hline Helodidae & 3 & 0 & 0 & 0 \\
\hline Hydrophilidae & 32 & 42 & 18 & 14 \\
\hline Latridiidae & 0 & 1 & 0 & 0 \\
\hline Leiodidae & 2 & 1 & 0 & 0 \\
\hline Ptilidae & 8 & 0 & 0 & 0 \\
\hline Rhizophagidae & 4 & 4 & 0 & 0 \\
\hline Scolytidae & 7 & 0 & 0 & 0 \\
\hline Silphidae & 36 & 86 & 120 & 134 \\
\hline Staphylinidae & 128 & 168 & 176 & 90 \\
\hline \multicolumn{5}{|l|}{ Carabidae species } \\
\hline Abax paralellepipedus & 243 & 527 & 295 & 233 \\
\hline Agonum emargiuatum & 1 & 0 & 0 & 0 \\
\hline Agonum fuliginosum & 1 & 2 & 0 & 0 \\
\hline Agonum muelleri & 1 & 0 & 0 & 0 \\
\hline Agonum viduum & 2 & 0 & 0 & 0 \\
\hline Bembidion lampros & 8 & 3 & 0 & 1 \\
\hline Bembidion tibale & 14 & 2 & 0 & 0 \\
\hline Cychrus caraboides & 1 & 7 & 1 & 2 \\
\hline Clivina fossor & 4 & 0 & 0 & 0 \\
\hline Carabus granulatus & 257 & 131 & 271 & 262 \\
\hline Calathus melanocephalus & 0 & 2 & 0 & 0 \\
\hline Carabus problematicus & 5 & 26 & 3 & 23 \\
\hline Elaphrus cupreus & 10 & 5 & 0 & 0 \\
\hline Loricera pilicornis & 35 & 51 & 7 & 1 \\
\hline Leistus terminatus & 2 & 2 & 7 & 1 \\
\hline Miscodera arctica & 0 & 1 & 0 & 0 \\
\hline Notiophilus biguttatus & 30 & 36 & 1 & 3 \\
\hline Nebria brevicollis & 1 & 6 & 49 & 45 \\
\hline Paranchus albipes & 0 & 1 & 0 & 0 \\
\hline Pterostichus aethiops & 0 & 0 & 2 & 0 \\
\hline Pterostichus madidus & 108 & 121 & 36 & 38 \\
\hline Pterostichus melanarius & 45 & 48 & 19 & 4 \\
\hline Pterostichus niger & 463 & 314 & 450 & 449 \\
\hline Pterostichus nigrita & 29 & 53 & 0 & 0 \\
\hline Pterosticus rhaeticus & 0 & 0 & 54 & 23 \\
\hline Pterostichus vernalis & 1 & 1 & 0 & 0 \\
\hline Trechus obtusus & 3 & 1 & 0 & 0 \\
\hline Trechus rubens & 0 & 0 & 6 & 8 \\
\hline Trechus secalis & 88 & 43 & 0 & 0 \\
\hline T.rechus quadrastriatus & 3 & 1 & 0 & 0 \\
\hline Unknown & 0 & 2 & 0 & 0 \\
\hline \multicolumn{5}{|l|}{ Saproxylic species } \\
\hline Agathidium marginatum & 0 & 1 & 0 & 0 \\
\hline Barypithes araneiformis & 42 & 45 & 0 & 0 \\
\hline Barypithes pellucidus & 0 & 1 & 0 & 0 \\
\hline Dolopius marginatus & 0 & 1 & 0 & 0 \\
\hline Helodes minuta & 2 & 5 & 0 & 0 \\
\hline Hylastes ater & 5 & 0 & 0 & 0 \\
\hline Hylobius abietis & 6 & 5 & 0 & 6 \\
\hline Hylurgops palliatus & 3 & 1 & 0 & 0 \\
\hline Liparus coronatus & 0 & 1 & 0 & 0 \\
\hline Nargus wilkli & 2 & 0 & 0 & 0 \\
\hline Otiorrhynchus singularis & 1 & 3 & 0 & 0 \\
\hline Strophosomus melanogrammus & 3 & 6 & 0 & 0 \\
\hline
\end{tabular}


(a)

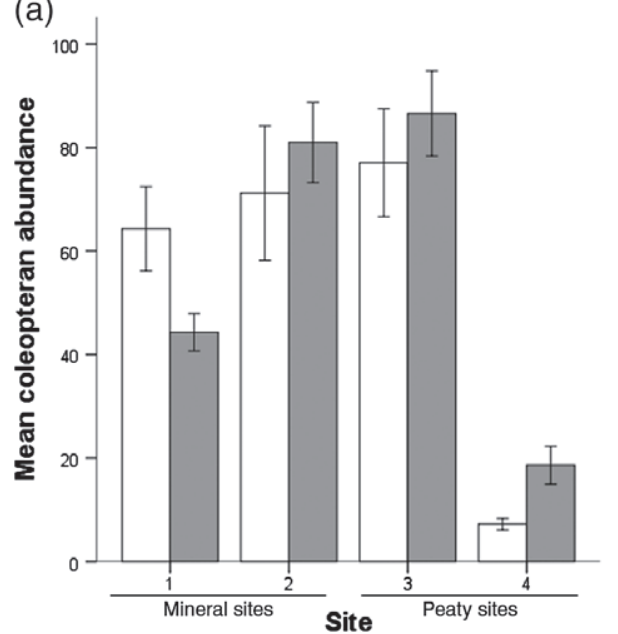

(b)

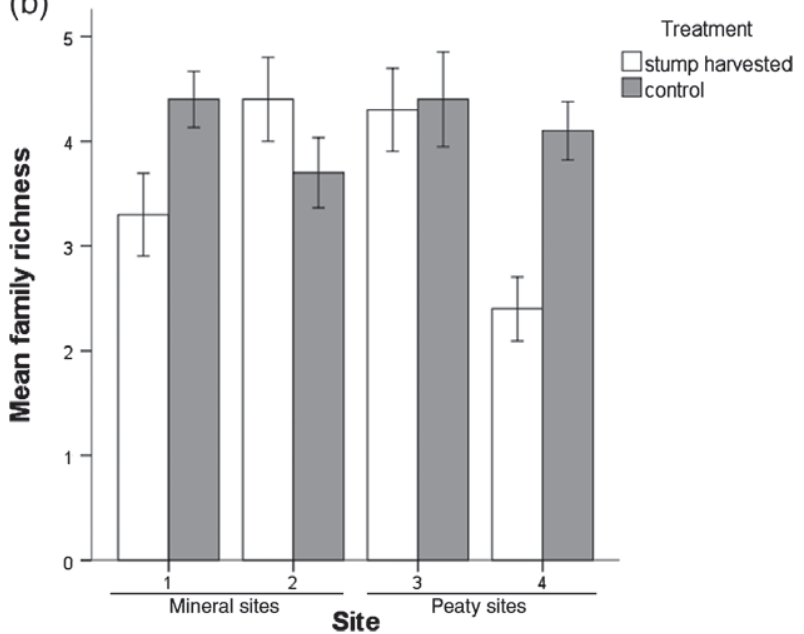

Figure 1 Mean \pm SE abundance (a) and family richness (b) of beetles at the different sites: Year 1.

\section{Year 1}

In Year 1, treatment (stump-harvested versus control) did not have a significant effect on the total abundance of Coleoptera, whereas site did. There was no significant interaction between the two variables. Figure 1(a) illustrates these data the family richness of Coleoptera was significantly affected by treatment, site and their interaction (Table 3). With the effect of treatment on family richness being contingent on site-specific factors, it is difficult to generalize on the effects of stump-harvesting on this variable. However, the sites in which family richness significantly differed between treatments (sites 1 and 4 ) showed a bias for control to be higher than the associated stump-harvested location (Fig. 1b).

For Carabidae, treatment (stump-harvesting versus control) did not have a significant effect on total abundance, whereas site had a significant effect on total abundance and there was no significant interaction between the two factors (site $\times$ treatment) (Fig. 2a) in Year 1 (Table 3). Carabid species richness did not differ between treatments, although it differed among sites and there was no significant site $\times$ treatment interaction (Fig. $2 \mathrm{~b}$ and Table 3).
For the wood-inhabiting (saproxylic) species identified in Year 1 , species richness and total abundance were influenced by site $(P<0.001$ in both cases) but not the stump-harvesting treatment ( $P=0.747$ for abundance and $P=0.649$ for species richness). There was no significant treatment $\times$ site interaction $(P=0.281$ for abundance and $P=0.189$ for species richness) (Fig. 3).

A more conservative analysis pools traps for each treatment and applies a generalized linear model with Poisson error distribution. In this analysis (Table 4), total abundance of Coleoptera is marginally nonsignificantly different between treatments $(P=0.11)$ in Year 1. However, given the results of the ANOVA, we may assume that there is likely an effect given the low statistical power of the generalized linear model.

\section{Year 2}

For Year 2 (2013), treatment (stump-harvesting versus control) did not had a significant effect on the total abundance of Coleoptera collected and, although site did have an effect, there was no site $\times$ treatment interaction (Fig. 4a and Table 3). The family richness of Coleoptera was also only significantly affected by site, although neither treatment, nor the site $\times$ treatment interaction was significant (Fig. 4b and Table 3).

Similarly, for Carabidae, neither treatment (stump-harvesting versus control), nor the site $\times$ treatment interaction had a significant effect on the total abundance of Carabidae collected (Fig. 5a and Table 3), whereas site did. Carabid species richness also only significantly differed among sites (Table 3 ) although there was a marginally nonsignificant effect of treatment on carabid species richness $(P=0.096)$ but no effect of site $\times$ treatment interaction (Fig. 5b and Table 3).

The only partially saproxylic family identified in Year 2 was the Curculionidae, which consisted of the large pine weevil (H. abietis) only. This species occurred with a low abundance (only six individuals), all of which occurred only on the control plot of Site 4 (Errill).

A more conservative analysis pools traps for each treatment and applies a generalized linear model with Poisson error distribution. In this analysis (Table 4), total abundance of Coleoptera is significantly different between treatments $(P<0.001)$ in Year 2 , with stump-harvested treatments being significantly more abundant than controls. It is also significantly different between treatments with respect to total Carabidae abundance $(P=0.029)$ in Year 2, with stump-harvested treatments being more abundant than controls.

\section{Effect of site, soil type and stump-harvesting on community composition}

Treatment (stump- harvested versus control) did not significantly affect the composition of coleopteran families or saproxylic species, although it did significantly affect the composition of carabid species, even if only weakly structuring the community and accounting for approximately $2 \%$ of the variation in the species matrix in the first year. In the second year of collections, neither coleopteran family composition, nor carabid species composition was affected by stump-harvesting treatment. The analysis clearly shows that site is a major factor in 
Table 3 Analysis of variance models for the effects of site and treatment (stump removal versus control) and their interactions on the total abundance of all Coleoptera, family richness of Coleoptera, total abundance of Carabidae and species richness of Carabidae for the 2 years treated separately

\begin{tabular}{|c|c|c|c|c|}
\hline Source & d.f. & MS & $F$ & $P$ \\
\hline \multicolumn{5}{|c|}{ Total abundance of all Coleoptera year 1 (adjusted $r^{2}=0.862$ ) } \\
\hline Model & 8 & 39461.488 & 63.232 & 0.000 \\
\hline Treatment & 1 & 143.112 & 0.229 & 0.633 \\
\hline Site & 3 & 19549.346 & 31.326 & 0.000 \\
\hline Treatment $\times$ Site & 3 & 1146.046 & 1.836 & 0.148 \\
\hline Error & 72 & 624.071 & - & - \\
\hline Total & 80 & & & \\
\hline \multicolumn{5}{|c|}{ Family richness of Coleoptera year 1 (adjusted $r^{2}=0.922$ ) } \\
\hline Model & 8 & 154.650 & 119.987 & 0.000 \\
\hline Treatment & 1 & 6.050 & 4.694 & 0.034 \\
\hline Site & 3 & 4.317 & 3.349 & 0.024 \\
\hline Treatment $\times$ Site & 3 & 5.650 & 4.384 & 0.007 \\
\hline Error & 72 & 1.289 & - & - \\
\hline Total & 80 & & & \\
\hline \multicolumn{5}{|c|}{ Total abundance of Carabidae year 1 (adjusted $r^{2}=0.800$ ) } \\
\hline Model & 8 & 15056.700 & 40.939 & 0.000 \\
\hline Treatment & 1 & 11.250 & 0.031 & 0.862 \\
\hline Site & 3 & 8609.117 & 23.408 & 0.000 \\
\hline Treatment $\times$ Site & 3 & 210.983 & 0.574 & 0.634 \\
\hline Error & 72 & 367.783 & - & - \\
\hline Total & 80 & & & \\
\hline \multicolumn{5}{|c|}{ Species richness of Carabidae year 1 (adjusted $\left.r^{2}=0.924\right)$} \\
\hline Model & 8 & 346.963 & 122.879 & 0.000 \\
\hline Treatment & 1 & 0.312 & 0.111 & 0.740 \\
\hline Site & 3 & 130.612 & 46.257 & 0.000 \\
\hline Treatment $\times$ Site & 3 & 6.079 & 2.153 & 0.101 \\
\hline Error & 72 & 2.824 & - & - \\
\hline Total & 80 & & & \\
\hline \multicolumn{5}{|c|}{ Total abundance of all Coleoptera year 2 (adjusted $r^{2}=0.869$ ) } \\
\hline Model & 8 & 17662.025 & 67.463 & 0.000 \\
\hline Treatment & 1 & 470.450 & 1.797 & 0.184 \\
\hline Site & 3 & 11651.483 & 44.505 & 0.000 \\
\hline Treatment $\times$ Site & 3 & 297.083 & 1.135 & 0.341 \\
\hline Error & 72 & 261.803 & - & - \\
\hline Total & 80 & & & \\
\hline \multicolumn{5}{|c|}{ Family richness of Coleoptera year 2 (adjusted $\left.r^{2}=0.855\right)$} \\
\hline Model & 8 & 57.512 & 60.100 & 0.000 \\
\hline Treatment & 1 & 0.113 & 0.118 & 0.733 \\
\hline Site & 3 & 13.279 & 13.877 & 0.000 \\
\hline Treatment $\times$ Site & 3 & 0.513 & 0.536 & 0.659 \\
\hline Error & 72 & 0.957 & - & - \\
\hline Total & 80 & & & \\
\hline \multicolumn{5}{|c|}{ Total abundance of Carabidae year 2 (adjusted $r^{2}=0.864$ ) } \\
\hline Model & 8 & 10880.412 & 64.734 & 0.000 \\
\hline Treatment & 1 & 137.813 & 0.820 & 0.368 \\
\hline Site & 3 & 6667.479 & 39.669 & 0.000 \\
\hline Treatment $\times$ Site & 3 & 278.513 & 1.657 & 0.184 \\
\hline Error & 72 & 168.079 & - & - \\
\hline Total & 80 & & & \\
\hline \multicolumn{5}{|c|}{ Species richness of Carabidae year 2 (adjusted $r^{2}=0.947$ ) } \\
\hline Model & 8 & 201.150 & 179.243 & 0.000 \\
\hline Treatment & 1 & 3.200 & 2.851 & 0.096 \\
\hline Site & 3 & 97.167 & 86.584 & 0.000 \\
\hline Treatment $\times$ Site & 3 & 0.767 & 0.683 & 0.565 \\
\hline Error & 72 & 1.122 & - & - \\
\hline Total & 80 & & & \\
\hline
\end{tabular}


(a)

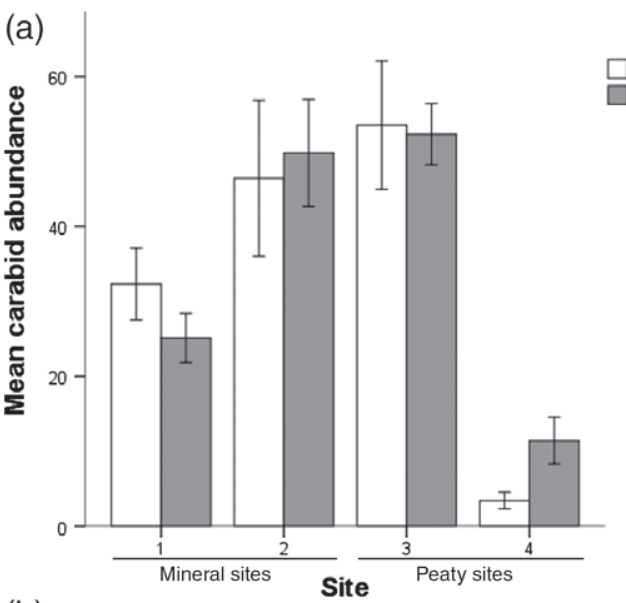

(b)

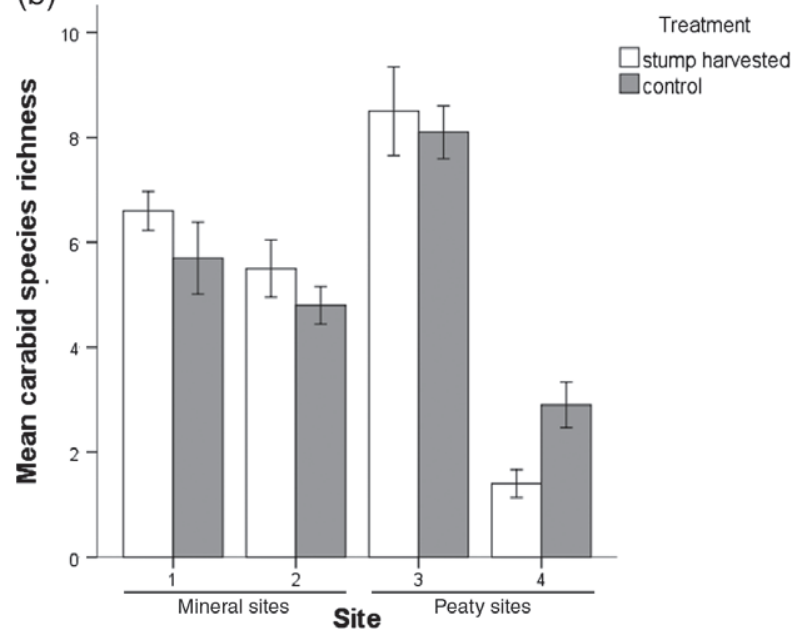

Figure 2 Mean \pm SE abundance (a) and species richness (b) of ground beetles (Carabidae) at the different sites: Year 1.

determining the composition of coleopteran families, carabid species and saproxylic species, explaining between $22 \%$ and $34 \%$ of the variation in the species matrix for both years of collection (Table 5). Soil type explains approximately $5 \%$ of the variation in carabid species and coleopteran family composition but approximately $21 \%$ of the variation in saproxylic species composition in Year 1 and approximately $10 \%$ of the variation in Year 2.

Indicator species analysis was performed on all data sets, although only the carabid data set gave significant indicators in Year 1. In Year 1, the common Carabus granulatus L. and Bembidion tibale (Duftschmid) were significant indicators of stump-harvested areas, which, together with the MRPP, indicates that community composition of Carabidae is likely to be affected by stump-harvesting initially. In the second year of collections, Curculionidae were a significant indicator of control sites, as was the carabid Carabus problematicus Herbst. Also, Loricera pilicornis (Fabricius), Leistus terminatus (Hellwig in Panzer) and Pterostichus melanarius (Illiger) were significant indicators of stump-harvested sites in the second year of collections (Table 6). Although forest and heathland species were indicative of control areas, open ground species, peatland species, stream
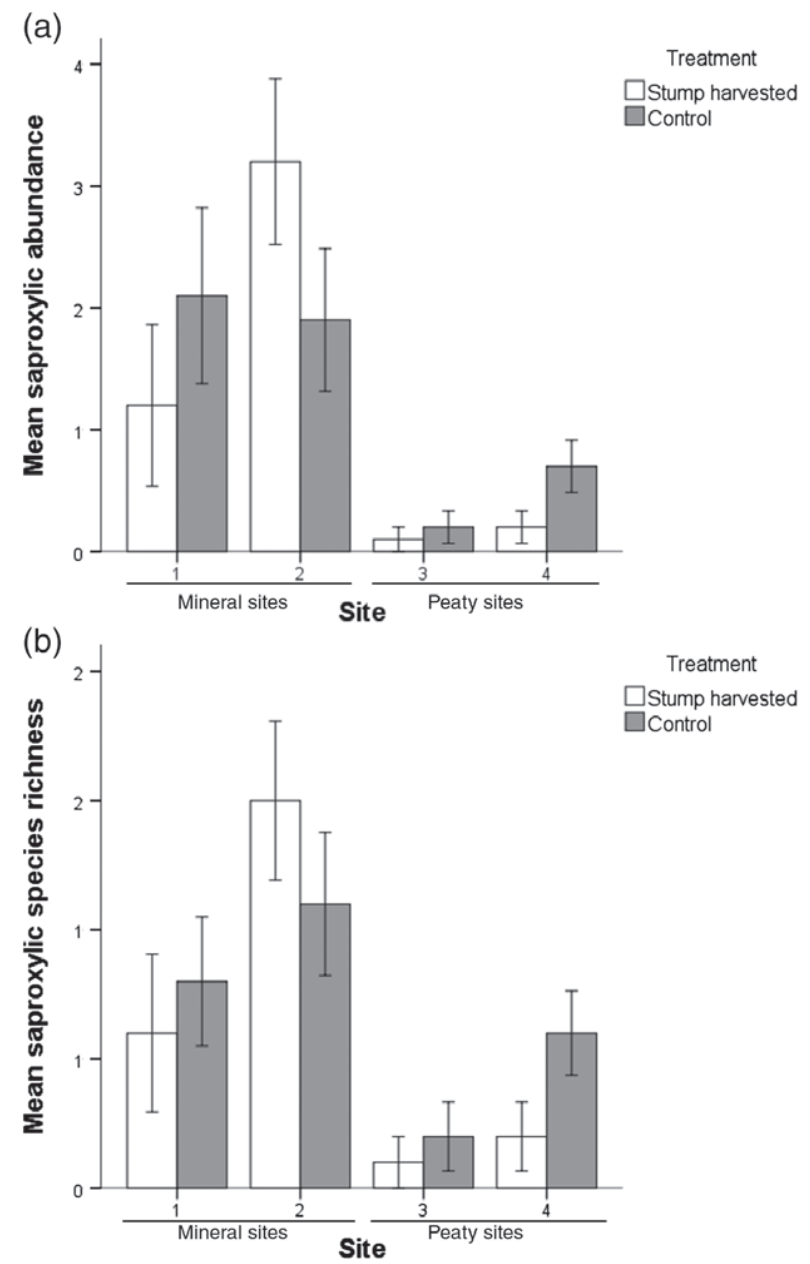

Figure 3 Mean \pm SE abundance (a) and species richness (b) of wood-inhabiting (saproxylic) species at each site: Year 1.

bank species, scrub and wet woodland species were indicative of areas where stumps were harvested.

To visualize carabid community composition, two NMS ordinations were performed: one for each year of collection. Figure 6 shows a similar dispersion of trap composition in species space, with site 4 showing a widely dispersed composition relative to the tight cluster of sites $1-3$. However, within the tight cluster of sites 1-3, there is a clear separation of stump-harvested traps from control traps in Year 1 but considerable overlap in Year 2. This reflects the results of the MRPP, which demonstrated compositional differences in Year 1 but not in Year 2.

\section{Discussion}

Stump-harvesting initially negatively affects beetle and carabid abundance, beetle family-richness and carabid species richness and community structure, although the effects are not large, are site-specific and are not persistent. However, it should be noted that beetles were collected later in the season in Year 2 and this may have affected beetle abundance, richness and composition. Therefore, further studies should investigate 
Table 4 Generalized linear model with Poisson error distribution and log link function treating each site as a replicate

\begin{tabular}{|c|c|c|c|}
\hline Source & d.f. & Wald chi-squared & $P$ \\
\hline \multicolumn{4}{|c|}{ Total abundance of all Coleoptera year 1} \\
\hline Intercept & 1 & 180486.533 & $<0.001$ \\
\hline Treatment & 1 & 2.542 & 0.111 \\
\hline \multicolumn{4}{|c|}{ Family richness of Coleoptera year1 } \\
\hline Intercept & & 354.439 & $<0.001$ \\
\hline Treatment & & 0.342 & 0.559 \\
\hline \multicolumn{4}{|c|}{ Total abundance of Carabidae year 1} \\
\hline Intercept & 1 & 93408.444 & $<0.001$ \\
\hline Treatment & 1 & 0.328 & 0.567 \\
\hline \multicolumn{4}{|c|}{ Species richness of Carabidae year 1} \\
\hline Intercept & 1 & 626.446 & $<0.001$ \\
\hline Treatment & 1 & 0.010 & 0.920 \\
\hline \multicolumn{4}{|c|}{ Total abundance of all Coleoptera year 2} \\
\hline Intercept & 1 & 100090.187 & $<0.001$ \\
\hline Treatment & 1 & 12.967 & $<0.001$ \\
\hline \multicolumn{4}{|c|}{ Family richness of Coleoptera year 2} \\
\hline Intercept & 1 & 81.023 & $<0.001$ \\
\hline Treatment & 1 & 0.111 & 0.739 \\
\hline \multicolumn{4}{|c|}{ Total abundance of Carabidae year 2} \\
\hline Intercept & 1 & 73489.565 & $<0.001$ \\
\hline Treatment & 1 & 4.792 & 0.029 \\
\hline \multicolumn{4}{|c|}{ Species richness of Carabidae year 2} \\
\hline Intercept & 1 & 124.116 & $<0.001$ \\
\hline Treatment & 1 & 0.813 & 0.367 \\
\hline
\end{tabular}

(a)

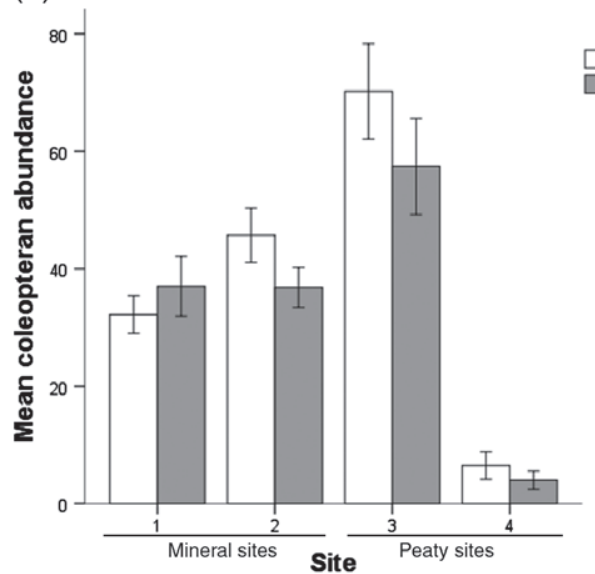

(b)

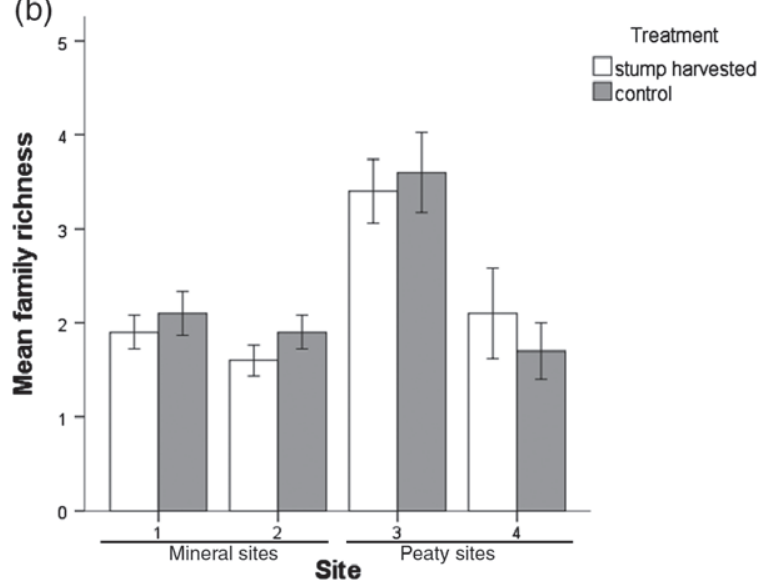

Figure 4 Mean \pm SE abundance (a) and family richness (b) of beetles at the different sites: Year 2.
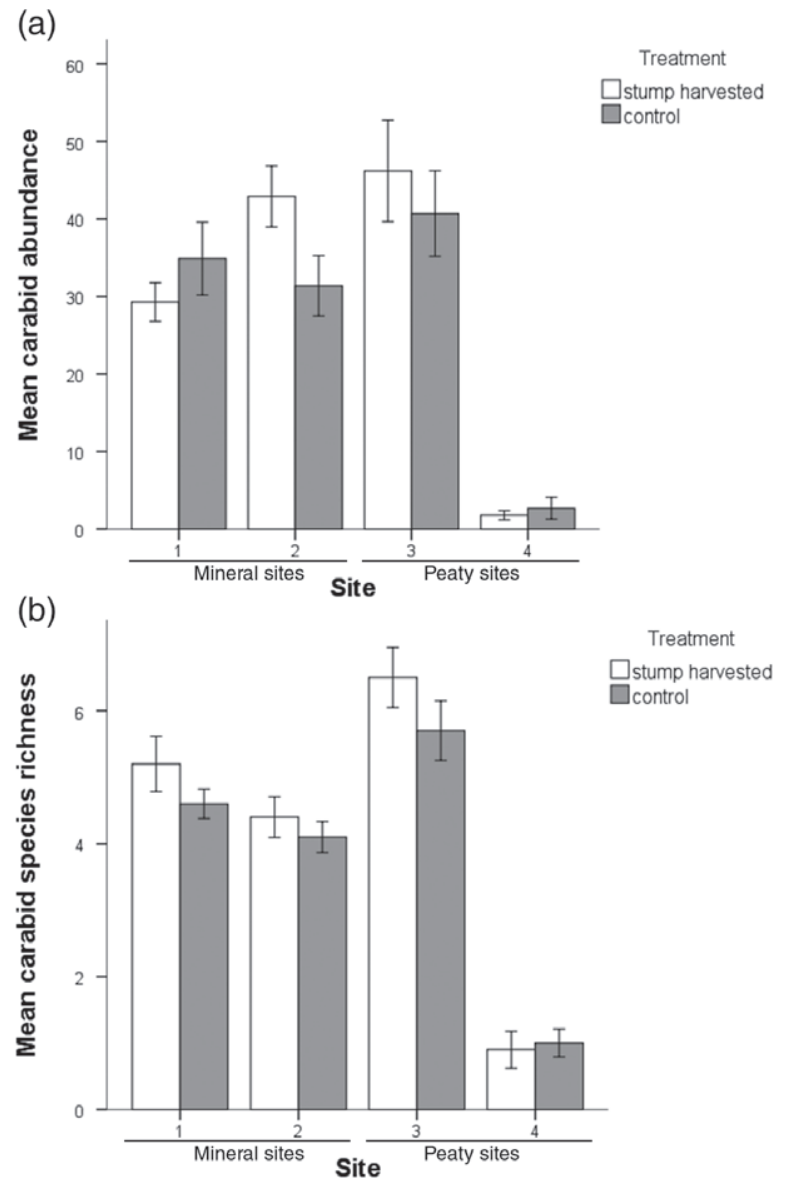

Figure 5 Mean \pm SE abundance (a) and species richness (b) of ground beetles (Carabidae) at the different sites: Year 2. 
Table 5 Multi-response permutation procedure showing the effects of treatment (stump harvested versus control), soil-type (peat versus mineral) and site (1-4) on the community structure of coleopteran families, carabid species and saproxylic species

\begin{tabular}{|c|c|c|c|c|}
\hline Year of sampling & Data set & Grouping variable & Chance-corrected within-group agreement $(A)$ & $P$ \\
\hline \multirow[t]{9}{*}{ Year 1} & \multirow[t]{3}{*}{ Coleoptera families } & Treatment & -0.0063 & 0.70 \\
\hline & & Soil type & 0.049 & $0.0042^{\star \star}$ \\
\hline & & Site & 0.33 & $<10^{-8 \star \star \star}$ \\
\hline & \multirow[t]{3}{*}{ Carabidae species } & Treatment & 0.017 & $0.023^{\star}$ \\
\hline & & Soil type & 0.059 & $2.2 \times 10^{-5 \star \star \star}$ \\
\hline & & Site & 0.24 & $<10^{-8 \star \star \star}$ \\
\hline & \multirow[t]{3}{*}{ Saproxylic species } & Treatment & -0.0048 & 0.52 \\
\hline & & Soil type & 0.21 & $1.1 \times 10^{-7 \star \star \star}$ \\
\hline & & Site & 0.22 & $1.4 \times 10^{-6 \star \star \star}$ \\
\hline \multirow[t]{6}{*}{ Year 2} & \multirow[t]{3}{*}{ Coleoptera families } & Treatment & -0.00463 & 0.616 \\
\hline & & Soil type & 0.0981 & $1.277 \times 10^{-5 * \star \star}$ \\
\hline & & Site & 0.346 & $<10^{-8 \star \star \star}$ \\
\hline & \multirow[t]{3}{*}{ Carabidae species } & Treatment & -0.00352 & 0.617 \\
\hline & & Soil type & 0.0957 & $2.3 \times 10^{-7 \star \star \star *}$ \\
\hline & & Site & 0.288 & 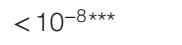 \\
\hline
\end{tabular}

${ }^{\star} P<0.05,{ }^{\star \star} P<0.01$ and ${ }^{\star \star *} P<0.001$

Table 6 Indicator species analysis showing significant $(P<0.1)$ carabid indicators of control and stump-harvested treatments and showing the sole significant family indicator in Years 1 and 2

\begin{tabular}{|c|c|c|c|c|}
\hline Species & Species classification & Maximum group & $\%$ perfect indication & $P$ \\
\hline \multicolumn{5}{|l|}{ Year 1} \\
\hline Abax parallelipipedus & Eurytopic/forest & Control & 42.4 & 0.0672 \\
\hline Carabus problematicus & Heath/forest & Control & 18.8 & 0.0470 \\
\hline Carabus granulatus & Peatland & Stump harvested & 48.0 & 0.0236 \\
\hline Bembidion tibale & Stream banks & Stump harvested & 15.8 & 0.0348 \\
\hline Bembidion lampros & Eurytopic/heath & Stump harvested & 11.3 & 0.0986 \\
\hline \multicolumn{5}{|l|}{ Year 2} \\
\hline Carabus problematicus & Heath/forest & Control & 20.9 & 0.0366 \\
\hline Loricera pilicornis & Open habitats & Stump-harvested & 11.9 & 0.0804 \\
\hline Leistus terminatus & Scrub/heath & Stump-harvested & 14.2 & 0.0496 \\
\hline Pterostichus melanarius & Wet woodland & Stump-harvested & 17.9 & 0.0774 \\
\hline Curculionidae & Forest & Control & 12.8 & 0.0518 \\
\hline
\end{tabular}

cursorial invertebrates at an earlier time in the season. Also studies on sites where a higher proportion of stumps are removed should be conducted. Indicator species analysis revealed that, although forest and heathland species were indicative of control areas (where stumps were left in situ), open ground species, peatland species, stream bank species, scrub and wet woodland species were indicative of areas where stumps were harvested. More individuals and species were collected in the first year of the study than the second. Differences in beetle numbers might not only be attributable to the loss of open-habitat species over time, but also could plausibly be explained by the later collection date of beetles in Year 2.

Clear-felled sites can support a far wider array of invertebrates than the plantations they replace (Day \& Carthy, 1988; Mullen etal., 2008), although it should be noted that forest specialist species may suffer as a result of this management. The invertebrates most likely to be impacted by stump-harvesting are those that inhabit the stumps themselves, and several studies have addressed the likely impacts of stump-harvesting on these so-called saproxylic beetles in Scandinavia (Hjältén et al., 2010; Andersson et al., 2012, 2015; Ols et al., 2013). In a study investigating the longer-term (21-28 years post-harvest) impacts of stump-harvesting on beetles using window trap collections, Andersson etal. (2012) found evidence for persisting minor effects of stump-harvesting on the species richness of beetles of the family Latridiidae and fungivores but, generally, the effects of stump-harvesting were small compared with the effects of surrounding landscape features. Jonsell and Schroeder (2014) quantified the proportions of landscape-wide populations of saproxylics that are recruited from clearfell stumps and Victorsson and Jonsell (2013b) compared stump faunas in stumps that were left on otherwise extracted sites and normal clearfells.

The most abundant family in our collections was ground beetles (Carabidae), accounting for $49 \%$ of the collected individuals. Because they were so abundant and are of value as indicator species, they were identified to species. Other Coleoptera, apart from those from known saproxylic families, were identified to family level only. Taxonomic minimalism (determining collections to taxa higher than species-level) has been critiqued (Goldstein, 1997, 1999) but has advantages in terms of the breadth of study made possible and the number of samples that can be determined efficiently (Oliver \& Beattie, 1996). Mandelik et al. (2007) have shown that, at the local level, family level 
(a)

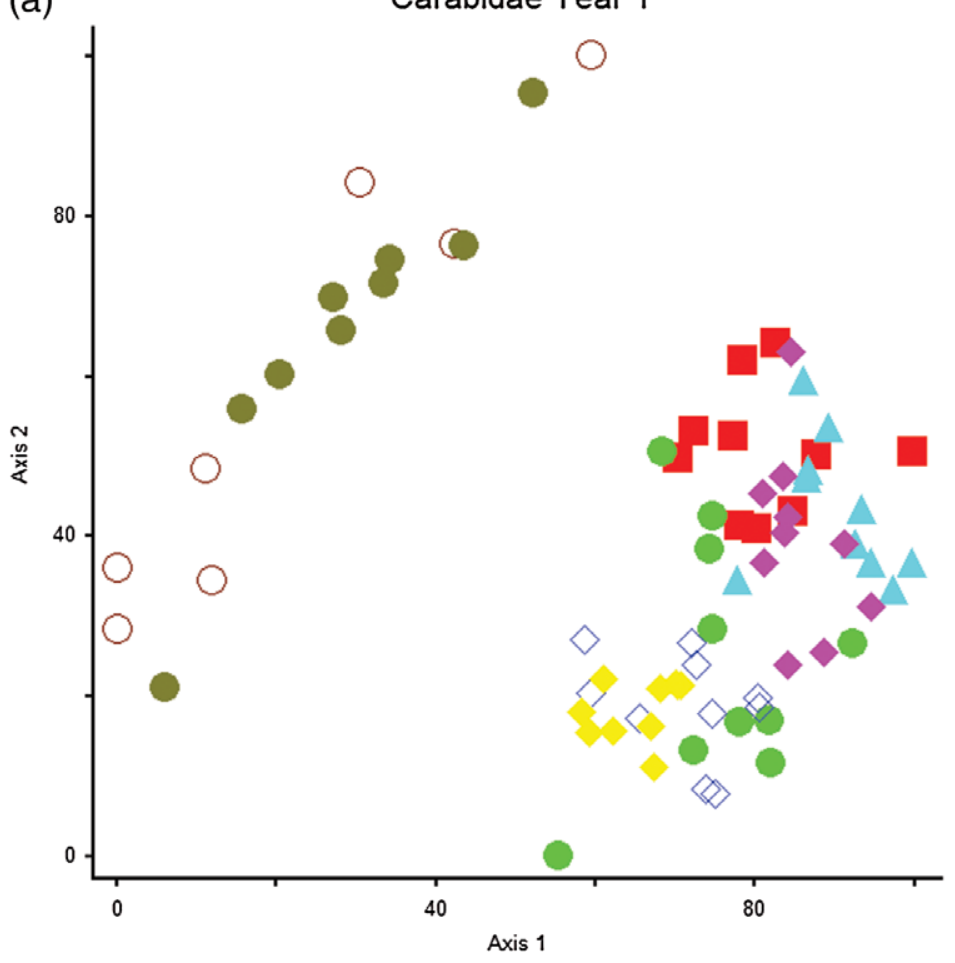

Sites and treatments

Site 1 stump-harvested

Site 1 control

Site 2 stump harvested

Site 2 control

$\checkmark$ Site 3 stump-harvested

Site 3 control

Site 4 stump-harvested

Site 4 control (b)

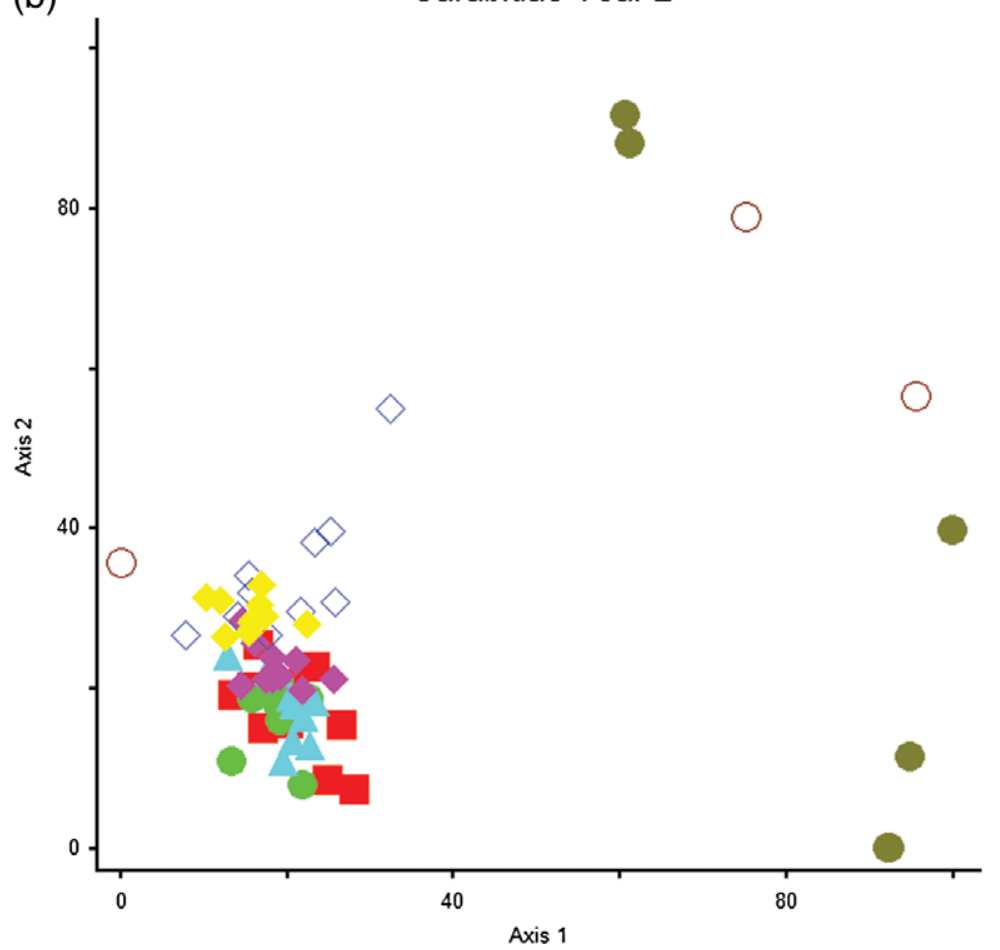

Axis 1
Sites and treatments

Site 1 stump-harvested

Site 1 control

Site 2 stump-harvested

Site 2 control

$\checkmark$ Site 3 stump-harvested

Site 3 control

Site 4 stump-harvested

Site 4 control

Figure 6 Non-metric multidimensional scaling ordination of pitfall traps in Carabidae species-space overlaid with site showing that most of the compositional differences were as a result of site-specific differences. (a) Year 1. Axis 1 accounted for approximately 55.9\% of the variation and axis 2 accounted for $20.9 \%$, as measured by the correlation coefficient between the distance in ordination space and in the original species space. Orthogonality between axis 1 and 2 was $95.6 \%$. (b) Year 2. Axis 1 accounted for approximately $73.6 \%$ of the variation and axis 2 accounted for $17.2 \%$, as measured by the correlation coefficient between the distance in ordination space and in the original species space. Orthogonality between axis 1 and 2 was $91.9 \%$. [Colour figure can be viewed at wileyonlinelibrary.com]. 
identification performs poorly compared with species or genus identification. However, for beetles, 'almost $70 \%$ of the variation in patterns of occurrence of beetle species were reflected in the family-level data' (Mandelik et al., 2007).

Community composition in the present study was significantly affected by site-specific factors and some of this variation could be explained by the difference in communities collected on mineral versus peaty sites. Initially, stump-harvesting weakly, but significantly, affected ground beetle (Carabidae) composition, with B.tibale and the common C.granulatus favouring stump-harvested sites. The former species is common on disturbed areas such as shingle by rivers and exposed gravel (Luff, 2007) and it is possible that the disturbance created by stump-harvesting directly favoured these species. Stump-harvesting did not appear to affect beetle family composition or saproxylic species composition, although, because only pitfall traps were used, this is only true with respect to cursorial saproxylics and a general reduction in saproxylics would be expected with the removal of so much habitat (Hjältén etal., 2010; Andersson etal., 2012, 2015; Ols etal., 2013). After the removal of stumps off site (Year 2 collections), there was no effect of stump-harvesting versus control on any of the variables. Hjältén etal. (2010) have shown that low stumps (i.e. stumps similar to those removed in the present study) can harbour as many saproxylics per unit volume as other substrates (high stumps and logs) and so retention of surface deadwood on a site may offer some mitigation. However, it should be noted that Ranius et al. (2014) demonstrated that it is hard to mitigate stump-harvesting by retaining other types of wood. Further mitigation measures include leaving some stumps in situ at sites where stump-harvesting was being undertaken. Because the present study relied on pitfall trapping, it is possible that many of the saproxylics initially collected on the stump-harvested areas were attracted by the large amounts of deadwood present in the wind-rows.

Walmsley and Godbold (2010) have noted that, although there have been no studies of the impact of stump-harvesting on ground-dwelling invertebrates at the time of their study (there have been some subsequently; see the Introduction to the present study), studies have shown that the retention of man-made high stumps (approximately $3 \mathrm{~m}$ ) can benefit saproxylic invertebrates, as well as specialized fungi (Anonymous, 2009). Current UK Forest Research guidelines (Anonymous, 2009) cover potential impacts of stump-harvesting only on soil and water. The present study suggests that ground dwelling beetles can also be significantly affected initially. It should be noted that many significance tests were performed and that, although it would be inappropriate in this instance to perform Bonferroni correction, we should consider mass significance and this further supports our conclusion that impacts are small, site-specific and not persistent.

The results of the present study generally agree with Andersson etal. (2012) who found that long-term effects of stumpharvesting on beetles were smaller than the site-specific differences. We have shown that the initial phase of stump-harvesting has noticeable effects on beetle communities, although these effects are site-specific. In particular, the community analysis, using NMS ordination, showed that site was a far more influential factor than treatment on beetle assemblages and that much of this variation may be attributed to soil type (peat versus mineral) as shown in the MRPP. The ordinations also generally supported the MRPP results in that treatment effects on composition were more clear in Year 1 than Year 2. Because most of the negative effects of stump-harvesting on coleopteran richness and abundance were found on a peaty site, we present tentative evidence that it is important to take soil type in to account when considering the feasibility of stump-harvesting and its effects on biodiversity.

\section{Acknowledgements}

This work was financially supported by Coillte. We thank the staff at Coillte for their assistance with emptying the traps. Our grateful appreciation is also extended to Ms Clare Finnegan who helped with some of the determinations. Finally, we thank Drs Roy Anderson and Keith Alexander for checking some of our determinations.

\section{Supporting information}

Additional Supporting information may be found in the online version of this article under the DOI reference:

10.1111/afe. 12218

Appendix S1. Abundance of families of Coleoptera collected at each trap (Year 1).

Appendix S2. Abundance of families of Coleoptera collected at each trap (Year 2).

Appendix S3. Abundance of species of Carabidae collected at each trap (Year 1).

Appendix S4. Abundance of species of Carabidae collected at each trap (Year 2).

Appendix S5. Abundance of saproxylics collected at each trap (Year 1). Year 2 saproxylics are not shown because there was only one species (Hylobius abietis) and all six individuals were collected in control traps.

\section{References}

Ågren, G.I. \& Hyvönen, R. (2003) Changes in carbon stores in Swedish forest soils due to increased biomass harvest and increased temperatures analysed with a semi-empirical model. Forest Ecology and Management, 174, 25-37.

Andersson, J., Hjältén, J. \& Dynesius, M. (2012) Long-term effects of stump harvesting and landscape composition on beetle assemblages in the hemiboreal forest of Sweden. Forest Ecology and Management, 271, 75-80.

Andersson, J., Hjältén, J. \& Dynesius, M. (2015) Wood-inhabiting beetles in low stumps, high stumps and logs on boreal clear-cuts: implications for dead wood management. PLOS ONE, 10, e0118896. DOI: 10.1371/journal.pone.0118896.

Anonymous2009) Stump Harvesting: Interim Guidance on Site Selection and Good Practice. Forest Research, U.K.

Battigelli, J.P., Spence, J.R., Langor, D.W. \& Berch, S.M. (2004) Short-term impact of forest soil compaction and organic matter removal on soil mesofauna density and oribatid mite diversity. Canadian Journal of Forest Research, 34, 1136-1149. 
Bouget, C., Lassauce, A. \& Jonsell, M. (2012) Effects of fuelwood harvesting on biodiversity - a review focused on the situation in Europe. Canadian Journal of Forest Research, 42, 1421-1432.

Day, K.R. \& Carthy, J. (1988) Changes in carabid beetle communities accompanying a rotation of sitka spruce. Agriculture, Ecosystems and Environment, 24, 407-415.

Egnell, G. (2016) Effects of slash and stump harvesting after final felling on stand and site productivity in Scots pine and Norway spruce. Forest Ecology and Management, 371, 42-49.

Eustafor (2010) Biomass and Bioenergy Report. Eustafor, Belgium.

Goldstein, P.Z. (1997) How many things are there? A reply to Oliver and Beattie, Beattie and Oliver, Oliver and Beattie, and Oliver and Beattie. Conservation Biology, 11, 571-574.

Goldstein, P.Z. (1999) Functional ecosystems and biodiversity buzzwords. Conservation Biology, 13, 247-255.

Hedman, L. (2008) Produktivitet vid stubbskörd, Vol. 219. Department of Forest Resource Management, SLU. Arbetsrapport/Sveriges Lantbruksuniversitet, Institutionen för skoglig resurshushållning, Swedish University of Agricultural Sciences, Sweden.

Hjältén, J., Stenbacka, F. \& Andersson, J. (2010) Saproxylic beetle assemblages on low stumps, high stumps and logs: implications for environmental effects of stump harvesting. Forest Ecology and Management, 260, 1149-1155.

Jonsell, M. \& Schroeder, L.M. (2014) Proportions of saproxylic beetle populations that utilise clear-cut stumps in a boreal landscape biodiversity implications for stump harvest. Forest Ecology and Management, 334, 313-320.

Jonsell, M., Hansson, J. \& Wedmo, L. (2007) Diversity of saproxylic beetle species in logging residues in Sweden - comparisons between tree species and diameters. Biological Conservation, 138, 89-99.

Joy, N.H. (1976) A Practical Handbook of British Beetles, 2 Vols.. E.W. Classey Ltd, Oxford.

Kataja-aho, S., Hannonen, P., Liukkonen, T., Rosten, H., Koivula, M.J., Koponen, S. \& Haimi, J. (2016) The arthropod community of boreal Norway spruce forests responds variably to stump harvesting. Forest Ecology and Management, 371, 75-83.

Kimmins, J.P. (1977) Evaluation of the consequences for future tree productivity of the loss of nutrients in whole-tree harvesting. Forest Ecology and Management, 1, 169-183.

Lee, S.-I., Spence, J.R. \& Langor, D.W. (2014) Succession of saproxylic beetles associated with decomposition of boreal white spruce logs. Agricultural and Forest Entomology, 16, 391-405.

Luff, M.L. (2007) The Carabidae (ground beetles) of Britain and Ireland. Handbook for the Identification of British Insects, 2nd edn, Vol. 4, part 2. Royal Entomological Society, U.K.

Malmström, A. (2012) Collembola in low stumps at clear-cuts. Is stump harvesting a threat? Scandinavian Journal of Forest Research, 27, 734-745.

Mandelik, Y., Dayan, T., Chikatunov, V. \& Kravchenko, V. (2007) Reliability of a higher-taxon approach to richness, rarity, and composition assessments at the local scale. Conservation Biology, 21, $1506-1515$.
Mann, L.K., Johnson, D.W., West, D.C. et al. (1988) Effects of whole-tree and stem-only clearcutting on postharvest hydrologic losses, nutrient capital, and regrowth. Forest Science, 34, 412-428.

McCune, B. \& Grace, J.B. (2002) Analysis of Ecological Communities. MjM Software Design, Gleneden Beach, Oregon.

McCune, B. \& Mefford, M.J. (1999) PC-ORD. Multivariate Analysis of Ecological Data. MjM Software Design, Gleneden Beach, Oregon.

Mullen, K., O'Halloran, J., Breen, J., Giller, P., Pithon, J. \& Kelly, T. (2008) Distribution and composition of carabid beetle (Coleoptera, Carabidae) communities across the plantation forest cycle implications for management. Forest Ecology and Management, 256, 624-632.

Nittérus, K., Åström, M. \& Gunnarsson, B. (2007) Commercial harvest of logging residue in clear-cuts affects the diversity and community composition of ground beetles (Coleoptera: Carabidae). Scandinavian Journal of Forest Research, 22, 231-240.

Oliver, I. \& Beattie, A.J. (1996) Invertebrate morphospecies as surrogates for species: a case study. Conservation Biology, 7, 562-568.

Ols, C., Victorsson, J. \& Jonsell, M. (2013) Saproxylic insect fauna in stumps on wet and dry soil: implications for stump harvest. Forest Ecology and Management, 290, 15-21.

Persson, T., Lenoir, L. \& Vegerfors, B. (2013) Which macroarthropods prefer tree stumps over soil and litter substrates? Forest Ecology and Management, 290, 30-39.

Rainio, J. \& Niemelä, J. (2003) Ground beetles (Coleoptera: Carabidae) as bioindicators. Biodiversity and Conservation, 12, 487-506.

Ranius, T., Caruso, A., Jonsell, M., Juutinen, A., Thor, G. \& Rudolphi, J. (2014) Dead wood creation to compensate for habitat loss from intensive forestry. Biological Conservation, 169, 277-284.

SPSS (2011) SPSS for Windows, Release 19.0.0. SPSS Inc., Chicago, Illinois.

Staaf, H. \& Olsson, B.A. (1994) Effects of slash removal and stump harvesting on soil water chemistry in a clearcutting in SW Sweden. Scandinavian Journal of Forestry, 9, 305-310.

Stenbacka, F., Hjältén, J., Hilszczański, J. \& Synesius, M. (2010) Saproxylic and non-saproxylic beetle assemblages in boreal spruce forests of different age and forestry intensity. Ecological Applications, 20, 2310-2321.

Victorsson, J. \& Jonsell, M. (2013a) Ecological traps and habitat loss, stump extraction and its effects on saproxylic beetles. Forest Ecology and Management, 290, 22-29.

Victorsson, J. \& Jonsell, M. (2013b) Effects of stump extraction on saproxylic beetle diversity in Swedish clear-cuts. Insect Conservation and Diversity, 6, 483-493.

Walmsley, J.D. \& Godbold, D.L. (2010) Stump harvesting for bioenergy - a review of the environmental impacts. Forestry, 83, 17-38.

Work, T.T., Brais, S. \& Harvey, B.D. (2014) Reductions in downed deadwood from biomass harvesting alter composition of spiders and ground beetle assemblages in jack-pine forests of Western Quebec. Forest Ecology and Management, 321, 19-28.

Accepted 22 January 2017

First published online 22 February 2017 